\title{
A redescription of pselaphochernes scorpioides (Hermann) (Pseudoscorpiones; Chernetidae)
}

\begin{abstract}
This paper provides a redescription of widely distributed pseudoscorpion Pselaphochernes scorpioides (Hermann, 1804) based on the newly collected specimens from Tehran and Fars Provinces, Iran.
\end{abstract}

Keywords: arachnida, pseudoscorpions, faunistic, the middle east, Iran

\author{
Volume 3 Issue 3 - 2018 \\ Mahrad Nassirkhani \\ Faculty of Agriculture and Natural Resources, Islamic Azad \\ University, Iran
}

Correspondence: Mahrad Nassirkhani, Entomology Department, Faculty of Agriculture and Natural Resources, Islamic Azad University, Arak branch, Arak, Iran, Tel +989| 314| 6830,Email greenartificialturfgrass@gmail.com

Received: May 20, 2018 | Published: June II, 2018
Abbreviations: eb, external basal; es $b$, external sub-basal; $i b$, internal basal; isb, internal sub-basal; ist, internal sub-terminal; est, external sub-terminal; it, internal terminal; et, external terminal; $t$, terminal; $b$, basal; $s b$, sub-basal; st, sub-terminal

\section{Introduction}

The genus Pselaphochernes Beier, 1932 currently contains 17 species, of which only two species were found in Iran: Pselaphochernes anachoreta (Simon, 1878) reported from Fars Province-southern Iran by Beier ${ }^{1}$ and Pselaphochernes scorpioides (Hermann, 1804) recorded from Guilan Province-northern Iran by Mahnert. ${ }^{2}$ In this contribution, P. scorpioides distributing around Europe, northern Africa, and the Middle East and Central $\mathrm{Asia}^{3}$ is redescribed and illustrated based on the specimens collected from central north and southern Iran, as new provincial records for the species.

\section{Material and methods}

The materials used in this study were examined and illustrated with an Olympus BH-2 compound microscope and drawing tube attachment. The specimens are lodged in Collection of the Acarology Laboratory, Islamic Azad University of Arak, Iran. The morphological terminology and mensuration follow. ${ }^{4-7}$

\section{Genus Pselaphochernes Beier, 1932}

The members of the genus Pselaphochernes can be separated from the other genera of the family by the following combination of characters: female spermathecae relatively short and T-shaped, each branch terminated to a huge vesicle; posterolateral corner of coxa IV normal; cheliceral rallum with three blades; and tarsus IV with a long tactile seta situated medially.

Pselaphochernes scorpioides (Hermann, 1804) (Figure 1-11), Pselaphochernes scorpioides (Hermann), Beier, 1932: 131.

\section{Material examined}

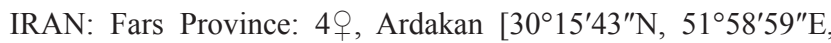
altitude 2200m], Sepidan, leaf litter, July 132015 , leg. M. Nassirkhani. Tehran Province: $10^{\prime}, 2$, Lavizan $\left[35^{\circ} 46^{\prime} 15^{\prime \prime} \mathrm{N}, 51^{\circ} 30^{\prime} 46^{\prime \prime} \mathrm{E}\right.$, altitude 1600m], Shemiran, decayed leaf litter, September 20 2013, leg. M.
Nassirkhani (IAUA).

\section{Redescription}

Adults. Body length: $1.75 \mathrm{~mm}(+2.12-2.32 \mathrm{~mm})$

Carapace: reddish brown; heavily granulate, not coarsely; L/W 1.12-1.21 ( $(1.00-1.10) ; 2$ transverse furrows present; with five pairs lyrifissures (Figure 1).

Tergites: reddish brown, intensively sclerotized, completely granulate; I-X with median suture line, XI not divided; half-tergites I-III without discal setae, IV with one lateral discal seta, $\mathrm{V}-\mathrm{X}$ with one lateral and one central discal seta; tergites $\mathrm{X}$ without long tactile setae; XI with four slightly long dentate setae; all setae short and stout with terminal denticulations; chaetotaxy 10:10:10:12:12:12:12:12:11-12:10-12:9$10: 2$ (요 8-10:10:10:10-11:12-13:12-13:12:12:12-13:10-12:8:2).

Sternites: brown, lighter in colour than tergites; lightly sclerotized; less granulate than tergites; IV-X with median suture line, XI undivided; females with T-shaped spermathecae, each arm end to a huge vesicle (Figure 2); XI with four relatively long setae; chaetotaxy 22-26:(1)8(1):(2)6(2):18:18:19:16:17:14:8:2 (ㅇ14:(1)10(1):(2)4(2):1 $5: 20: 20: 18: 18: 16: 8: 2)$.

Pleural membrane: longitudinally roughly striate.

Chelicera: light brown; galea short with indistinct rami in males (Figure 3), and in females long, with 6 rami (divided medially to two branches, each with 3 terminal rami) (Figure 4); fixed finger with 4 retrorse teeth; movable finger with galeal seta situated distally, with one point and large sub-apical tooth; hand weakly sclerotized, with 5 setae, $b, s b$ and $e s$ dentate (Figure 5); rallum with 3 blades, distal blade longest and denticulate (Figure 6) serrula exterior and interior present; serrula exterior with $17-19$ blades.

Pedipalps: reddish brown, darker in colour than carapace; intensively sclerotized; completely granulate, chelal fingers finely granulate; coxa with 19-21 setae, a few setae denticulate, with two distinct lyrifissures, manducatory lobe with 2 mariginal and 3 discal simple setae; trochanter swollen, with 2 dorsal rounded humps (Figure 7), L/W 1.81-1.87 (ㅇ.82-2.05); femur L/W 2.50-2.61 (인.75-2.83); patella with 2 lyrifissures situated basally (Figure 7), L/W 2.04-2.20 
(\$2.27-2.40); chela (with pedicel) L/W 3.20-3.33 (\$3.13-3.29); chela (without pedicel) L/W 2.96-3.04 (\$2.93-2.96); hand (with pedicel) L/W 1.64-1.75 ( $+1.73-1.81)$; movable finger slightly shorter than hand (with pedicel); hand (with pedicel) 1.02-1.05 (ㅇ 1.08-1.13) times longer than movable finger; fixed finger with 8 and movable finger with 4 trichobothria (Figures 8,11); fixed finger with 35-36 and movable finger with 36-38 cusped teeth (ㅇ 36-39 with and 36-41 with teeth); movable finger with 4-5 exterior accessory teeth, and fixed finger with 5-7 exterior accessory teeth (Figure 11); fixed finger with 7-9 sensory spots, mostly located basally (Figure 11); movable finger with two sensory spots located between trichobothria $s b$ and $s t$; venom apparatus present only in movable finger, nodus ramosus situated at same level as st.

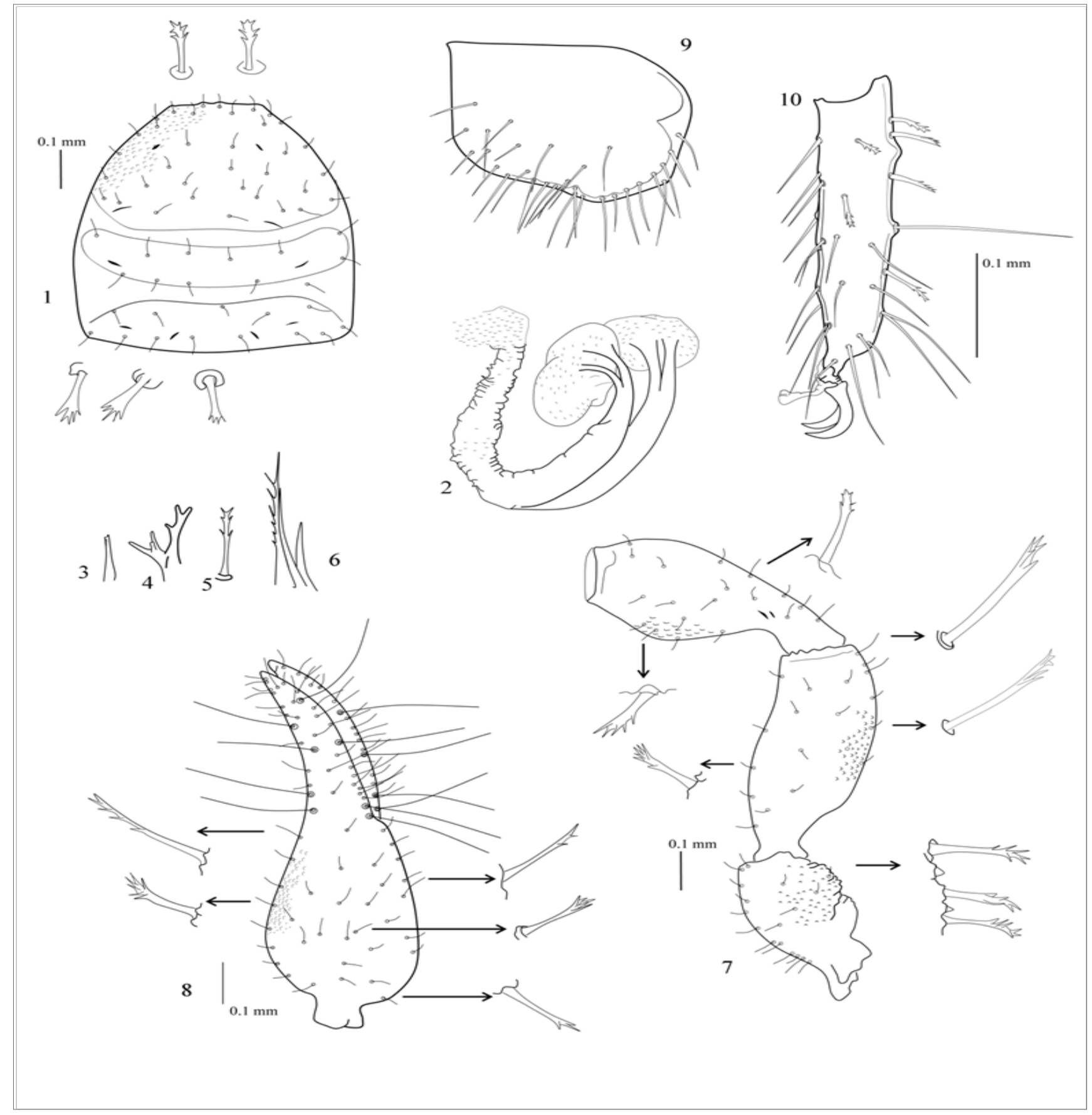

Figures I-I0 Pselaphochernes scorpioides (Hermann, 1804), + : I. carapace, dorsal view (setae magnified, granulation pattern shown partly); 2. spermatheca; 3. galea $\left({ }^{3}\right)$; 4. galea, female; 5 . dentate seta on cheliceral hand; 6. rallum; 7. basal segments of pedipalp, dorsal view (setae magnified, granulation pattern shown partly); 8. right chela, dorsal aspect; 9 . left coxa I; 10. tarsus IV. 


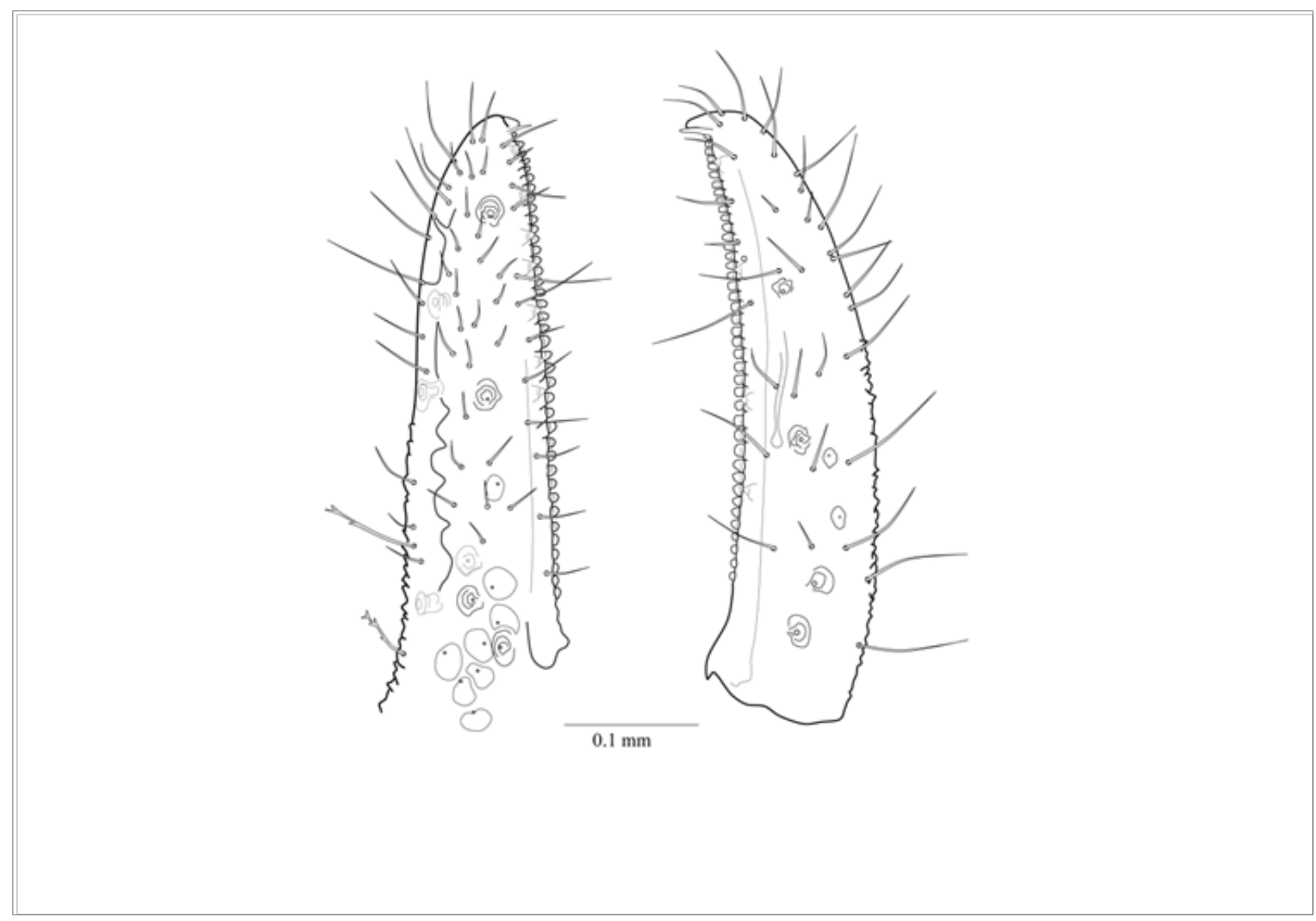

Figure II Pselaphochernes scorpioides (Hermann, 1804), ᄋ: left chelal fingers, lateral view (showing trichobothriotaxy, chelal teeth, and position of nodus ramosus).

Legs: brown; granulate; sub-terminal setae curved and simple; arolia simple and shorter than claws; claws smooth and symmetrical; coxal setae arranged: 12:12-14:16-18:24-28 (ㅇ 12-13:12-14:15-18:2837 ); coxal setae simple and acute; coxa IV with normal shape (Figure 9); prolateral margin of all segment with simple setae, retrolateral margin with denticulate setae; leg I: tibia L/D 3.33 ( $93.43-4.00$ ); tarsus L/D 4.40-4.60 (\$5.40-5.60); leg $I V$ : tibia+patella L/D 3.90-4.18 (93.84-4.00); tibia without tactile seta, L/D 3.55-4.00 (\$3.90-4.62); tarsus with a long tactile seta situated medially (TS $=0.5$ ), retrolateral margin with one bulge situated proximal to tactile seta (Figure 10 ), L/D 4.33-4.66 (†5.00-5.16).

\section{Dimensions in $\mathbf{m m}$}

Carapace: 0.58/0.48. Pedipalp: trochanter 0.29/0.16; femur $0.47 / 0.18$; patella $0.43 / 0.21$; chela (with pedicel) $0.80 / 0.24$; chela (without pedicel) 0.73 ; hand (with pedicel) L. 0.42 ; movable finger L. 0.40. Leg I: femur 0.14-0.17/0.09-0.10; patella 0.20-0.25/0.08-0.09; tibia 0.20/0.06; tarsus 0.22-0.23/0.05. Leg IV: femur 0.16-0.17/0.10; patella $0.31-0.34 / 0.11$; Femur+patella $0.43-0.46$; tibia $0.32 / 0.08$ 0.09; tarsus $0.26-0.28 / 0.06$. + Carapace: $0.60-0.65 / 0.60$. Pedipalp: trochanter $0.31-0.35 / 0.17-0.19$; femur $0.51-0.55 / 0.18-0.20$; patella $0.48-0.50 / 0.20-0.22$; chela (with pedicel) $0.87-0.94 / 0.27-0.30$; chela (without pedicel) $0.80-0.88$; hand (with pedicel) L.0.48-0.52; movable finger L. $0.45-0.47$. Leg I: femur $0.17-0.18 / 0.10-0.11$; patella 0.24 $0.26 / 0.09$; tibia $0.24-0.26 / 0.06-0.07$; tarsus $0.27-0.28 / 0.05$. Leg IV: femur $0.17-0.18 / 0.11$; patella $0.34-0.36 / 0.12-0.13$; Femur + patella $0.48-0.50$; tibia $0.35-0.37 / 0.08-0.09$; tarsus $0.30-0.31 / 0.06$.

\section{Remarks}

The pedipalps of Pselaphochernes scorpioides (Hermann, 1804) collected from central north and southern Iran and from Turkey [8] are slightly longer and thinner than the specimens collected from Europe e.g. the pedipalpal hand (without pedicel) size is $0.43 / 0.29 \mathrm{~mm}\left({ }^{\Uparrow}\right)$ and $0.48 / 0.31$ ( 9 ) for the European specimens. ${ }^{9-10}$ The pedipalp of the female from Pakistan, the only other described specimen from the Middle East, is distinctly longer than that of the previously studied specimens, e.g. the pedipalpal femur size is $0.69 / 0.22 \mathrm{~mm}$, chela (with pedicel) is $1.20 / 0.38 \mathrm{~mm}$, chelal hand (with pedicel) is $\mathrm{L} .070 \mathrm{~mm}$ and the movable chelal finger $\mathrm{L}$. is $0.61 \mathrm{~mm} .{ }^{11} \mathrm{In}$ due attention to the morphometric characters, the type of the cheliceral setae [see 12: Figure. 17], the position of a tactile seta on tarsus IV [see 12: Figure. 16], and the tergal setae arrangement [see 12: Figure 16], the specimen from Pakistan is very close to Pselaphochernes macrochaetus Redikorzev, 1949 which was synonymized with $P$. scorpioides by Schawaller. ${ }^{13}$ Based on the type of the cheliceral setae ( $b$ and $s b$ dentate in the female from Pakistan), numbers of accessory teeth on the chelal fingers (the fixed chelal finger of the Pakistani female bears five and the movable chelal finger only two exterior accessory teeth), the shape of spermathecae (see 11: Figure. 148), and the position of a tactile seta on tarsus IV (slightly distal to middle in 
the types and in the female from Pakistan [see 11: Figure. 149], the Pakistani female differs from $P$. scorpioides. Total of these differences raises the possibility of revalidation of $P$. macrochaetus, but still the types must be reexamined to clarify.

Pselaphochernes anachoreta (Simon, 1878) the only other species found in Iran can be recognized from P. scorpioides by the Pedipalpal size, e.g. femur is $0.69 / 0.30 \mathrm{~mm}$, chelal hand (without pedicel) is $0.64 / 0.37 \mathrm{~mm}$, and movable finger is $0.62 \mathrm{~mm}\left(\delta^{7}\right)(00.62 / 0.25 \mathrm{~mm}$, $0.60 / 0.37 \mathrm{~mm}$, and $0.50 \mathrm{~mm}){ }^{9,10}$ Pselaphochernes scorpioides is probably more widespread throughout the country than the present records indicate. It favors rich decaying organic material and is often found in synanthropic habitats such as compost, manure, dung and straw debris. This species has also been found in leaf litter, dead woods and the nests of the red-ant Formica rufa and is commonly phoretic on flies. ${ }^{14}$

\section{Acknowledgments}

The author is very grateful to Mr. Mahmoud Nassirkhani for his assistance.

\section{Disclosure statement}

The author declares that he has no competing interest and has not a financial relationship with the organization that sponsored the research.

\section{References}

1. Beier M. Pseudoscorpione aus dem Iran. Analen Naturhistorisches Museum in Wien. 1971;(75):357-366.

2. Mahnert V. Roncus viti $n$. sp. (Arachnida, Pseudoscorpiones) aus dem Iran. Berichte des Naturwissenschaftlich-Medizinischen Vereins in Innsbruck. 1974;61:87-91.

3. Harvey MS. Pseudoscorpions of the world. Australia: Western Australian Museum; 2013.
4. Chamberlin JC. The arachnid order Chelonethida. Stanford University Publications. 1931;7(1):1-284.

5. Harvey MS. The phylogeny and classification of the Pseudoscorpionida (Chelicerata: Arachnida). Invertebrate Taxonomy. 1992;(6):1373-1435.

6. Harvey MS, Ratnaweera PB, Randeniya PV, et al. A new species of the pseudoscorpion genus Megachernes (Pseudoscorpiones: Chernetidae) associated with a threatened Sri Lankan rainforest rodent, with a review of host associations of Megachernes. Journal of Natural History. 2012;46(42):2519-2535.

7. Judson ML. A new and endangered species of the pseudoscorpion genus Lagynochthonius from a cave in Vietnam, with notes on chelal morphology and the composition of the Tyrannochthoniini (Arachnida, Chelonethi, Chthoniidae). Zootaxa. 2007;1627(1):53-68.

8. Sezek F, Özkan M. The morphological features of the development stages of Pselaphochernes scorpioides (Hermann, 1804) (Arachnida, Pseudoscorpionida). Turkish Journal of Zoology. 2007;(31):19-26.

9. Beier M. Pseudoscorpionidea II. Subord, Cheliferinea. Tierreich. 1932;58:1-294.

10. Beier M. Ordnung Pseudoscorpionidea (Afterskorpione). In Bestimmungsbücher zur Bodenfauna Europas, volume 1. Berlin: Akademie-Verlag; 1963.

11. Dashdamirov S. Pseudoscorpions from the mountains of northern Pakistan (Arachnida: Pseudoscorpiones). Arthropoda Selecta. 2005;(13):225-261.

12. Redikorezev VV. Pseudoscorpions of Middle Asia. Travaux de l'Institut de Zoologie de l'Académie des Science de l'URSS. 1949;(8):638-668.

13. Schawaller W. Pseudoskorpione aus der Sowjetunion, Teil 3 (Arachnida: Pseudoscorpiones). Stuttgarter Beiträge zur Naturkunde. 1989;(440):130 .

14. Beier M. Phoresie und Phagophilie bei Pseudoscorpionen. Österreichische Zoologische Zeitschrift. 1948;(1):441-497. 